\title{
Livestock population dynamics and pastoral communities adaptation to rainfall variability in communal lands of Kgalagadi South, Botswana
}

\author{
Olaotswe E Kgosikoma ${ }^{1 *}$ and Nnyaladzi Batisani ${ }^{2}$
}

\begin{abstract}
Rainfall variability is a problem in arid environments, and in this study, drought severity, impact of rainfall variability on livestock population and adaptation practices were investigated in Kgalagadi, Botswana. Data from the Department of Meteorological Services, Central Statistics Office and a structured questionnaire were collected and analysed. Kgalagadi district is highly vulnerable to recurring mild droughts. The livestock population, particularly the goat population, thus tends to be positively associated with mean annual precipitation. Though cattle also responded positively to mean annual rainfall, the relationship was not statistically significant and this could be due to the buffering impact of management practices. Pastoral farmers adaptation practices included destocking, supplementation and mobility. The current grazing policy which promotes fencing could therefore increase the pastoral farmers vulnerability to droughts, as it limits mobility.
\end{abstract}

Keywords: Adaptation; Climate variability; Drylands; Pastoral ecosystems

\section{Background}

The ecosystems in semi-arid and arid environments are characterized by high inter-annual rainfall variability and reoccurring droughts (Ellis and Swift 1988; Mogotsi et al. 2012) which are likely to be exacerbated by climate change (IPCC 2013). In Africa, the agro-pastoral production systems are mostly vulnerable to increased climate variability (Stige et al. 2006; Sithole and Murewi 2009) as they are principally dependant on natural resources (Stringer et al. 2009). The traditional beef sector in Botswana is highly vulnerable to drought (Thomas et al. 2000) and climate change (Masike and Urich 2008). Thus, increased climate variability is likely to negatively impact the livelihoods of pastoral communities in semi-arid and arid environments (McCabe 1987), and there is an urgent need to develop robust adaptation strategies in such regions (Sulieman and Elagib 2012). But development of adaptation strategies requires clear understanding of the impact of rainfall variability on different ecosystems, particularly those that support already vulnerable societies (Stige et al. 2006).

\footnotetext{
* Correspondence: mfana450@yahoo.com

'Department of Agricultural Research, Private Bag 033, Gaborone, Botswana Full list of author information is available at the end of the article
}

In accordance with the non-equilibrium concept, rainfall variability is considered a principal regulator of plant productivity in semi-arid regions (Ellis and Swift 1988) and subsequently has a strong influence on livestock population dynamics (Begzsuren et al. 2004; Ogutu et al. 2007). The vegetation dynamics of some drylands are under the control of climate rather than grazing pressure and exhibit non-equilibrium dynamics (Westoby et al. 1989). Subsequently, the population of livestock such as cattle are likely to be driven by climate shocks (e.g. droughts) (Oba 2001) that lead to increased mortality. Pastoralists and farmers in semi-arid environments have therefore developed adaptation strategies to reduce the impact of drought on their livestock. Traditionally, pastoralists used mobility as an adaptive strategy to climatic shocks such as droughts. But the combined effect of increased climatic shocks, policies that limit mobility (e.g. fencing of communal land) and a lack of alternative viable livelihood options has made pastoral communities much more vulnerable to poverty (e.g. Sulieman and Elagib 2012), particularly those in sub-Saharan Africa (Thornton et al. 2009).

The role of rainfall variability on dryland ecosystems is still highly debated (Wehrden et al. 2012; Vetter 2005), 
and there is still limited understanding of interactions between livestock systems and climatic variability, especially how they may evolve in response to climatic changes in the future (Thornton et al. 2009). Thus, it is essential to understand how different livestock species are able to cope with shifts in environmental conditions (Best et al. 2007), especially extreme weather conditions. The current study investigates the impact of rainfall variability on livestock population dynamics and communities adaptation practices. Specifically, the objectives of this study are to (i) characterize drought severity, (ii) determine association between rainfall variability and livestock population dynamics and (iii) determine drought adaptation strategies in Kgalagadi South district, Botswana. Improved understanding of traditional management systems to climate variability is a prerequisite to developing adaptation strategies (McCabe 1987) to climate variability and future climate change.

\section{Study area}

The study was conducted in Kgalagadi South district, specifically Bokspits, located in the south-west of Botswana (Figure 1). The site was selected because it is one of the most arid parts of Botswana, and therefore, pastoral communities in this region are the most vulnerable to climatic variability. Hence, their challenges and coping strategies to rainfall variability could provide insights into what to expect in response to climate change. Kgalagadi district covers a total area of 105,200 $\mathrm{km}^{2}$ and constitutes a large part of the Kgalagadi (Kalahari) desert ecosystem.

The climatic condition at Bokspits is arid, characterized by low rainfall of about $181.015 .4 \mathrm{~mm}$ (1975 to 2012), with high temporal $(\mathrm{CV}=53.3 \%)$ and spatial fluctuations. The trend analysis indicates an increasing annual rainfall (Figure 2). Rainfall falls mostly from November to March, and therefore, there is an extended dry season which influences forage production from the rangeland.

The natural ecosystem varies from sandveld with bare rolling dunes covered by grasslands to low shrubland and shrub savanna along the Nossop and the Molopo rivers (Burgess 2003); the soil is dominantly Kalahari sandy soil. The major land use in this district is dominated by wildlife conservation and pastoral farming such that about one third of the total area of the district is part of Kgalagadi Transfrontier Park. However, livestock production is the main economic activity, partly because low rainfall and poor soil fertility cannot support arable farming. The pastoral farming in Kgalagadi district is dominated by traditional production systems characterized by continuous grazing of livestock in communally

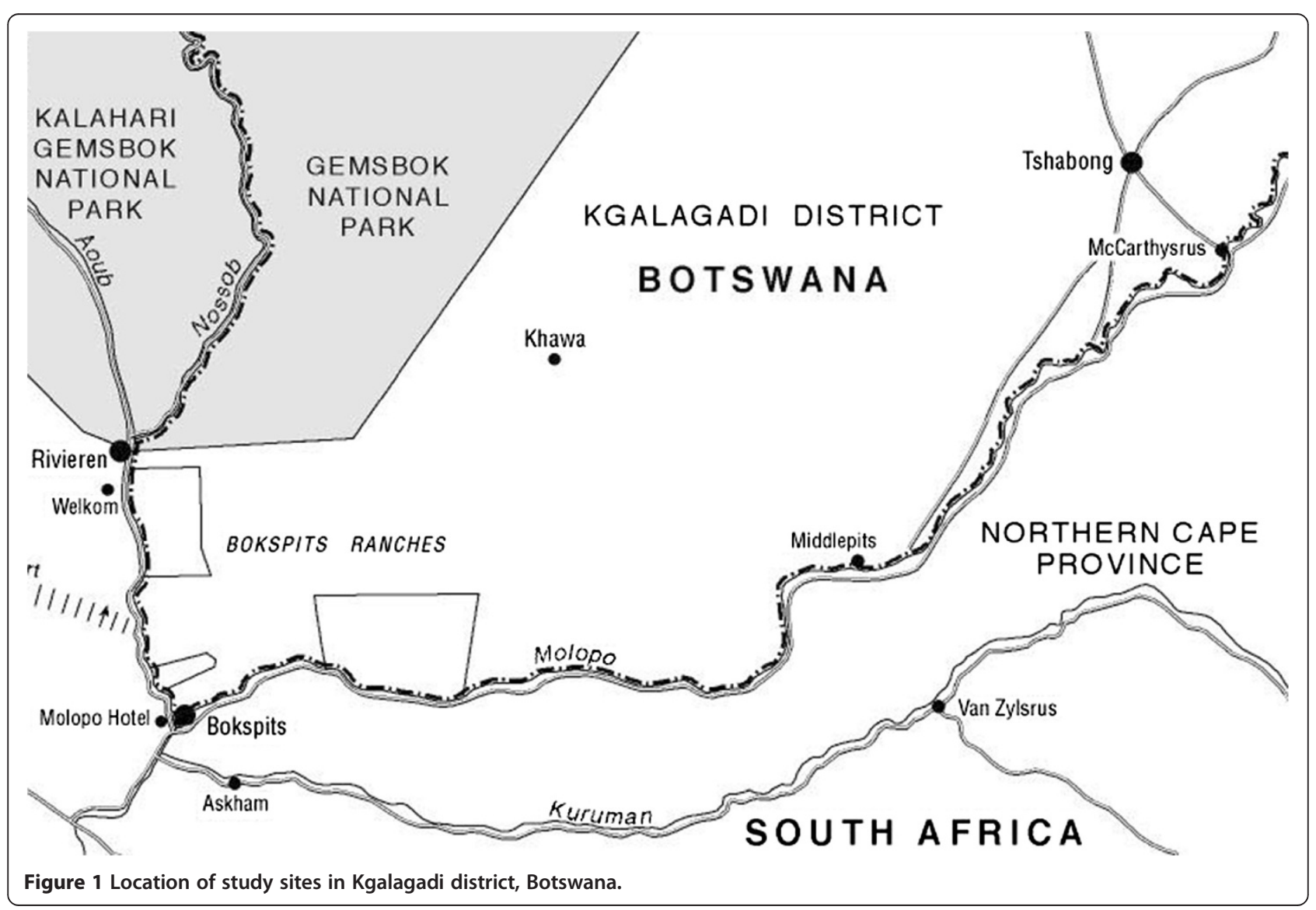




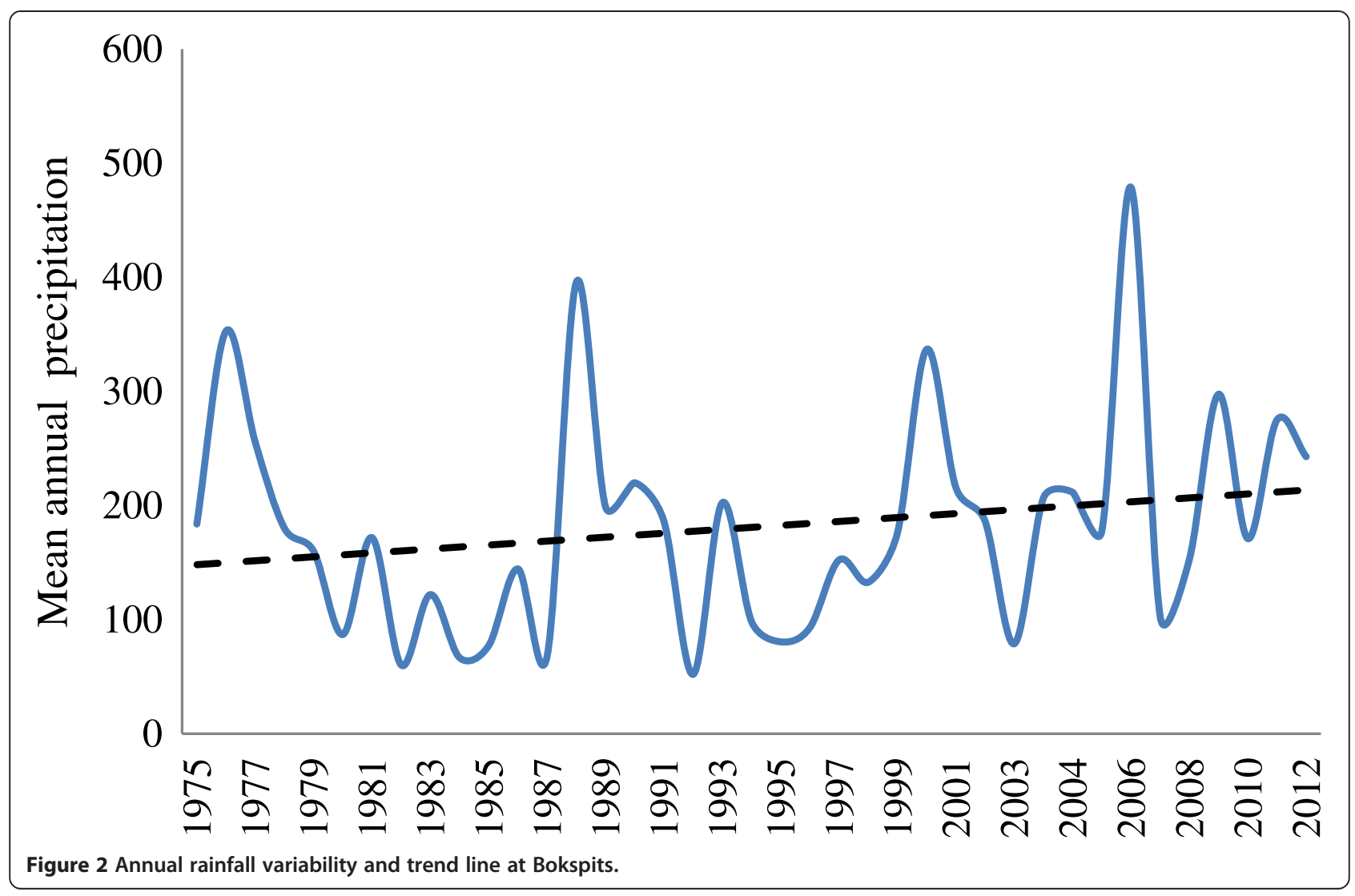

shared land. Cattle and goats are the main livestock species reared, but sheep are widely owned in Kgalagadi South. This region is sparsely inhabited by about 42,000 people (CSO 2001), and Tsabong town is the administrative centre for the district.

\section{Methods}

The monthly rainfall data for Bokspits, located in Kgalagadi South, was obtained from the Department of Meteorological Services, the national authority on climate data collection. Bokspits was selected because the data for this village was available over 30 years (1975 to 2012) and therefore represents a long-term perspective. Longduration records were also desirable for calculating the Standardized Precipitation Index (SPI), as providing more reliable statistics. The SPI is used to assess the seriousness of drought conditions as shown in Table 1. In addition, Bokspits rainfall was also representative of Kgalagadi South area, and its low rainfall is likely to be limiting to livestock population growth.

In terms of livestock population dynamics, only data for dominant species (cattle and goats) was collected from the Government Statistics Unit. The time series on livestock populations and production performance indicators were based on annual surveys undertaken by the Agricultural Statistics Unit of the Central Statistics Office (CSO) in collaboration with the Division of Agricultural Planning and Statistics (DAPS). The production performance indicators referred to birth rates, death rates and off-take rates for each livestock species, shown in Table 2. The birth rate is the ratio of total number of births to total number of female animals (e.g. cows) during the survey year. The death rate is the ratio of total number of deaths over total number of animals during the survey year, while the offtake rate is the ratio of off-take (Sales - Purchase + Home slaughter) over total number of animals during the survey year (CSO 1996). The livestock data under the traditional production system was available for a period of 20 years from 1980 to 2003 with data gaps for 1991, 1992, 2000, 2004 and 2005 due to no data collection during those

Table 1 SPI values and corresponding drought categories

\begin{tabular}{ll}
\hline SPI values & Drought category \\
\hline 2.0 and above & Extremely wet \\
1.5 to 1.99 & Very wet \\
1.0 to 1.49 & Moderately wet \\
-.99 to .99 & Near normal \\
-1.00 to -1.49 & Moderate drought \\
-1.50 to -1.99 & Severe drought \\
$\leq-2.0$ & Extreme drought \\
\hline
\end{tabular}


Table 2 Livestock performance indicators in Kgalagadi communal area

\begin{tabular}{lll}
\hline Performance indicators & Cattle & Goats \\
\hline Birth rate & $51.89 ? 3.84$ & $42.66 ? 1.23$ \\
Death rate & $14.32 ? 2.25$ & $27.86 ? 2.78$ \\
Off-take & $10.32 ? 0.80$ & $12.15 ? 0.98$ \\
\hline
\end{tabular}

particular years. The limitation of the current data is lack of livestock populations at local community scale, and hence, data presented is at district level.

A structured questionnaire consisting of both open- and close-ended questions was used to collect data on the peoples adaptation strategy to drought. Pastoral farmers, selected from alternating households from a random starting point, were asked about the strategies they practised to mitigate the impact of drought on livestock. The sample size in Bokspits $(n=40)$ was small, and therefore, the questionnaire was also administered to the neighbouring village of Vaalhoek $(n=31)$, about $5 \mathrm{~km}$ from Bokspits and therefore shares communal rangelands. Bokspits and Vaalhoek had about 105 and 51 households, respectively (IVPBOT 03, 2004). Two local enumerators were used to administer the questionnaire so that they could explain the questions clearly to respondents.

\section{Statistical analysis}

Monthly rainfall data was used to calculate the SPI. A software known as SPI_SL_6.exe file downloaded online (http://drought.unl.edu/monitor/spi/program/spi.program. htm) was used to calculate the SPI from monthly rainfall data. Regression analysis in Minitab was used to determine associations between livestock populations and rainfall variability. The chi-square test in SPSS was used to compare adaptation strategies adopted by pastoral communities at Bokspits and Vaalhoek.

\section{Results}

\section{Drought characteristics in Kgalagadi}

Precipitation in Bokspits fluctuated highly temporally as reflected by changes in SPI over the years as shown in Figure 3 and high rainfall coefficient of variation (53.3\%). Both 12- and 24-month SPI indicated that drought is a recurring environmental problem as several SPI were negative; this was further supported by the high rainfall coefficient of variation. In particular, 1987 depicted an extremely dry year, followed by a wet year. However, extreme wet and dry periods based on the 12-month SPI were rare $(2.7 \%$ and $1.6 \%$, respectively) during the observed period (445 months). Most of the time (70\%), the SPI indicated that precipitation was near normal to mild drought $(0$ to -.99$)$ and then followed by

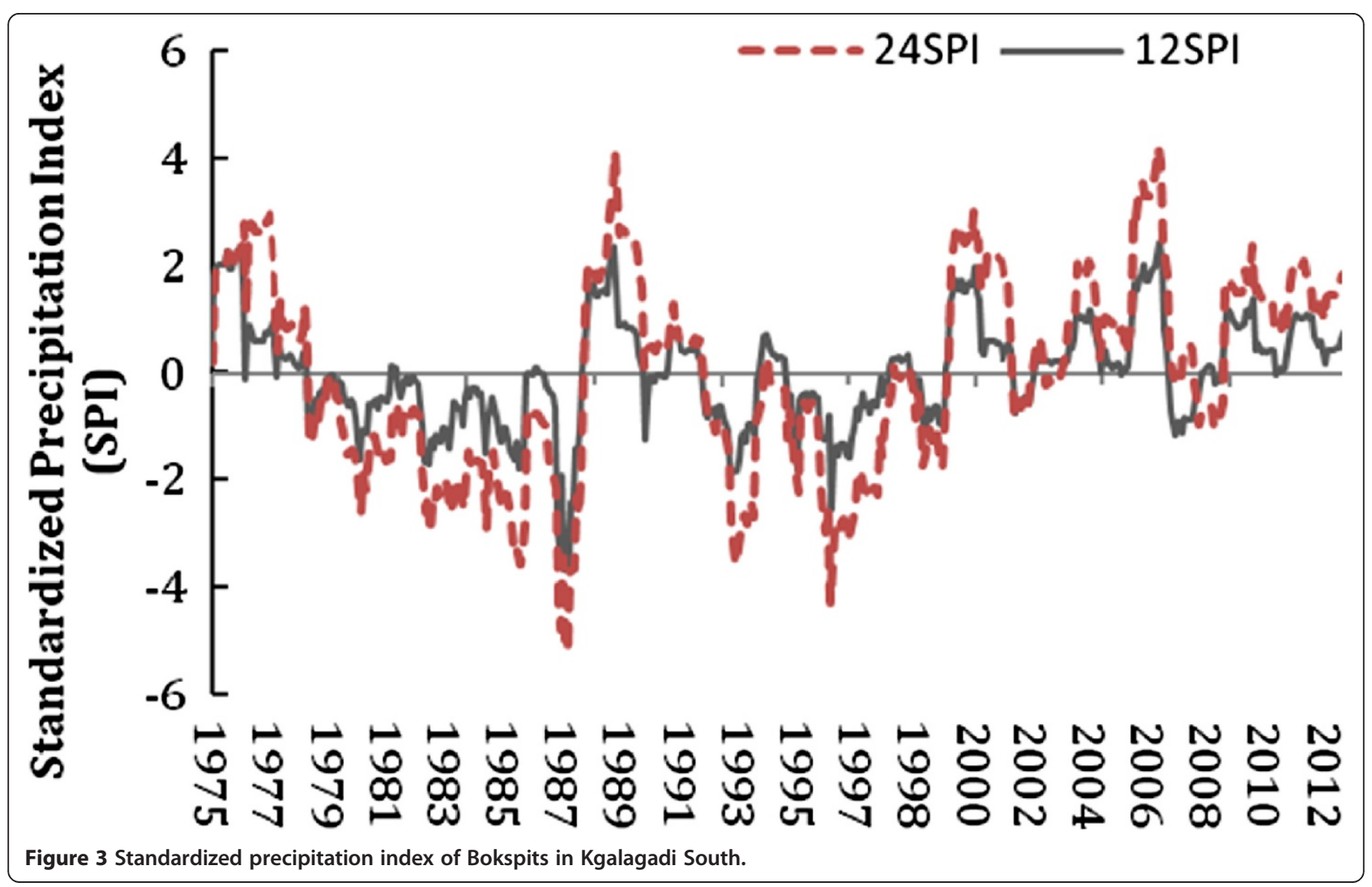


moderately dry periods (10\%). The SPI also indicated that drought frequencies had declined since around 2000 at Bokspits relative to the previous period. The 24-month SPI showed an increased frequency and severity of drought in Bokspits.

\section{Association between rainfall variability and livestock population dynamics}

In general, the livestock population increased with increasing mean annual rainfall. This is illustrated by a positive association observed between the goat population and mean annual rainfall. The mean annual rainfall of Bokspits accounted for $43.4 \%\left(r^{2}\right)$ of goat population variability $(P<0.01)$ (Figure 4$)$. The goat death rate also decreased with increasing mean annual rainfall $(P<0.05)$ (Figure 5). The goat population in the study area was also positively correlated to the cattle population $(r=0.80$, $P<0.001)$.

However, the cattle population was not significantly associated with Bokspits mean annual rainfall $(P>0.05)$, and only a small variability of the cattles population was accounted for by Bokspits mean annual rainfall (Figure 6).
The communities adaptation to rainfall variability

The pastoral community applied different drought coping strategies to reduce the impact of drought on their livestock (Table 3). The pastoralists at Bokspits and Vaalhoek tend to destock during droughts. All pastoralists at Vaalhoek indicated that they supplement their livestock, compared to $80 \%$ of pastoralists at Bokspits who indicated that they supplement. Mobility was still practised at both sites, mostly at Bokspits as an alternative adaptation strategy.

\section{Discussion}

\section{Drought characteristics in Kgalagadi}

Rainfall in Kgalagadi was characterized by high temporal variability and high rainfall coefficient of variation. This indicates that the Kgalagadi ecosystem is likely to exhibit non-equilibrium dynamics as suggested by Ellis and Galvin (1994) and thus have implications for rangeland and livestock management (Oba et al. 2000). Precipitation largely ranged between normal and mild droughts, which tends to be consistent with another study conducted in other parts of Botswana (Batisane 2011). Such recurring

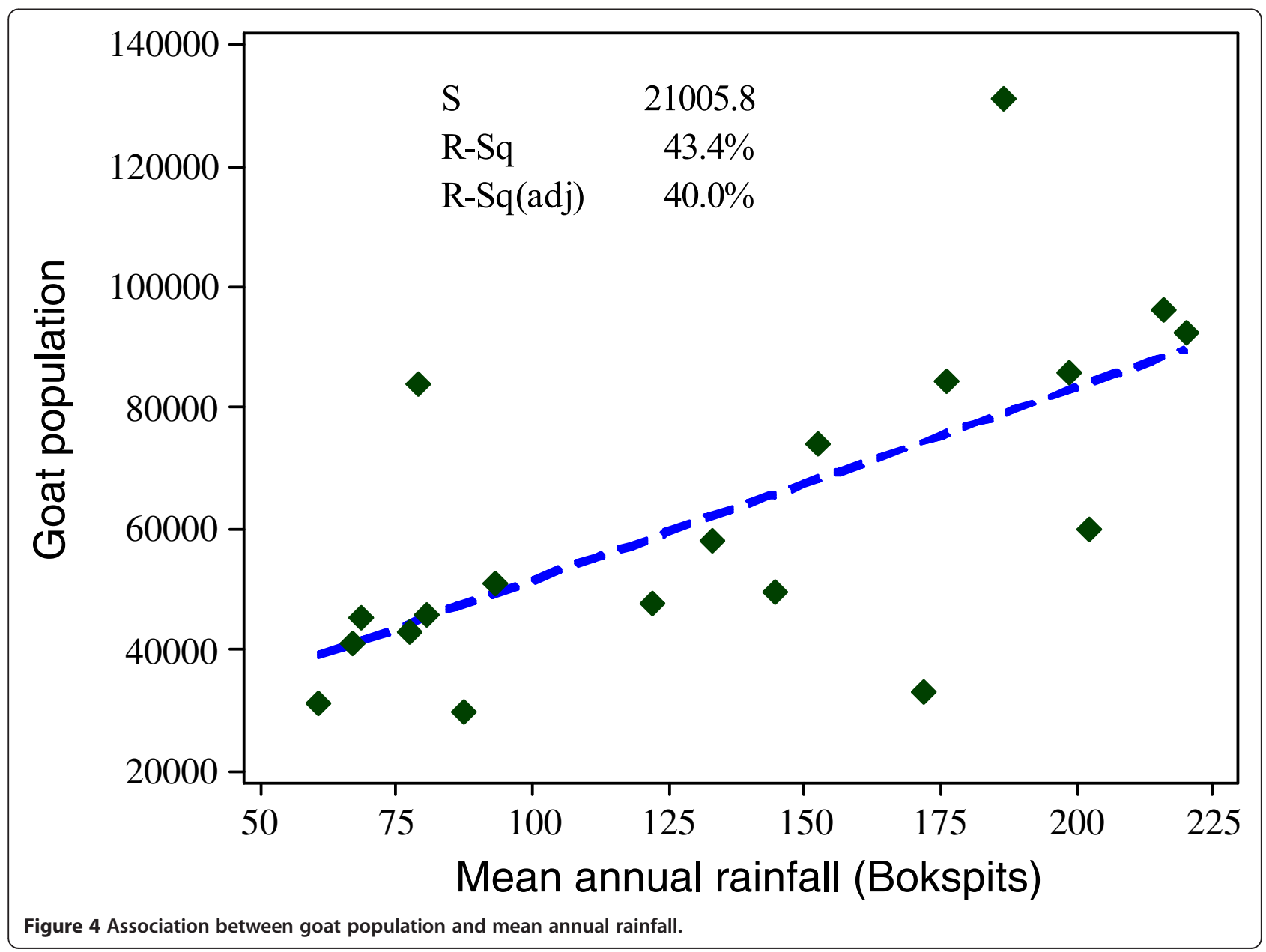




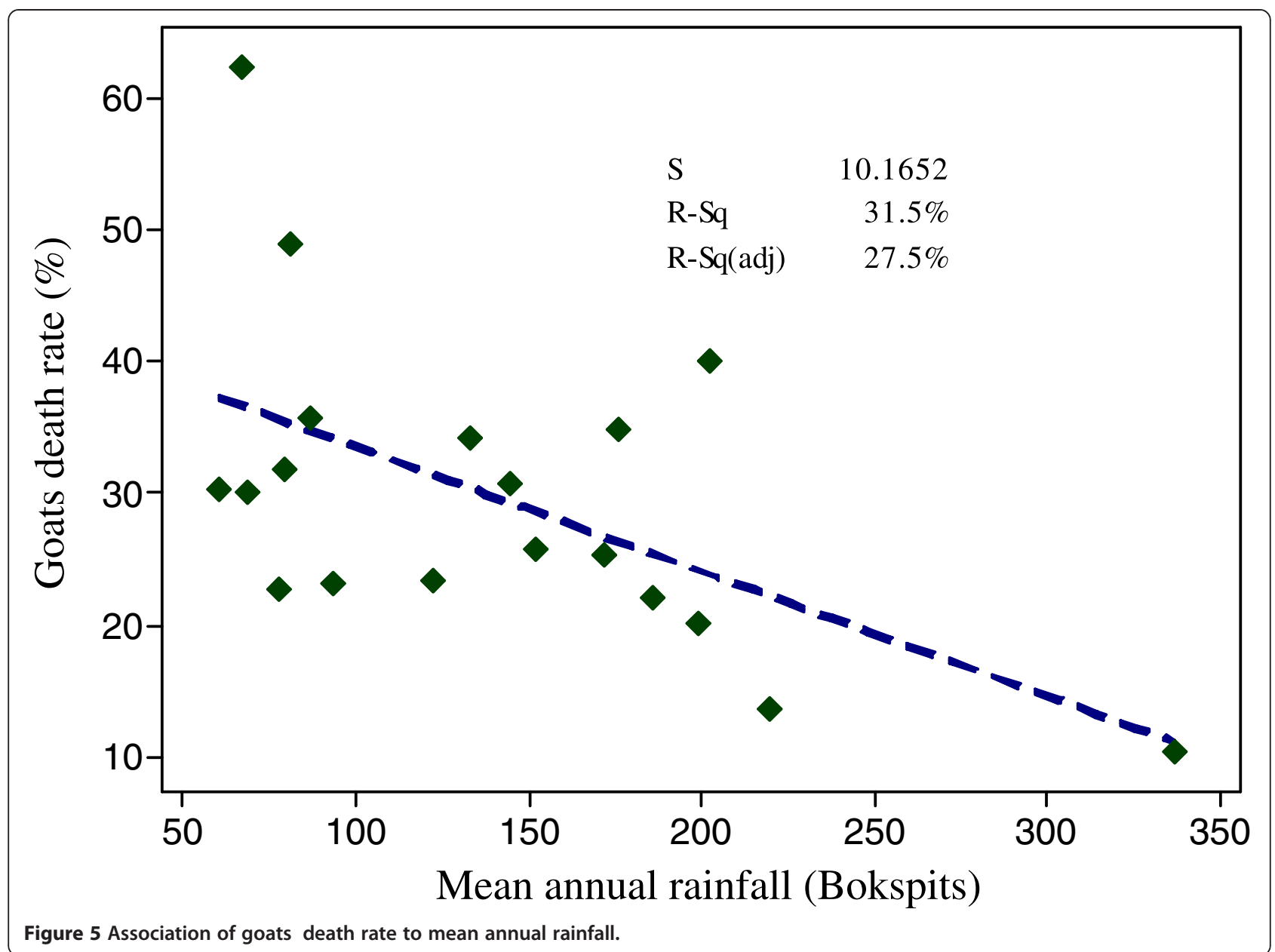

droughts, though mild, have the ability to create poverty traps especially for already vulnerable groups such as women (Sherwood 2013), particularly in areas like Bokspits where alternative livelihood options are limited. The SPI for Bokspits also revealed that drought frequencies had decreased in the last decade relative to previous decades. This observation needs to be investigated further because it is contrary to the thinking that southern Africa is likely to get drier due to climate change and consequently has high occurrences of rainfall extreme events (Lioubimtseva and Henebry 2009; Eriksen and Silva 2009).

\section{Association between rainfall variability and livestock population dynamics}

The livestock population in Kgalagadi followed a boom and bust pattern such that the population increases for a couple of years and then crashed, as suggested in other studies in Botswana (Perkins 1991) and elsewhere (McCabe 1987; Desta and Coppock 2002). This is consistent with a non-equilibrium ecosystem (Angassa and Oba 2007). In our study, livestock populations generally increased with increasing rainfall, which could be explained partially by the importance of rainfall on vegetation production (Ward et al. 2004). In this study, the goat population was moderately associated with mean annual precipitation and basically decreased during drought years. A possible explanation could be that higher precipitation facilitates feed availability during the dry season, which subsequently minimizes mortality and increases births, leading to increased goat populations (Mapiye et al. 2009). However, goats are known to be resilient to harsh conditions (Toulmin 1996), which is contrary to the observation of our study. The reason goats are responsive to rainfall variability in this study could be that they do not forage far from the degraded ranges around homesteads (McCabe 1987) as they have to return to the kraal at night and are thus more vulnerable to fluctuations in forage supply. An alternative explanation could be that goats, unlike cattle, are reared by almost every household in the study area and most goats are not supplemented with feed, unlike cattle owned by better-off households. In addition, the market for goats in Botswana is not well-organized, compared to the cattle market, and therefore, opportunities to destock goats during a drought year are limited. 


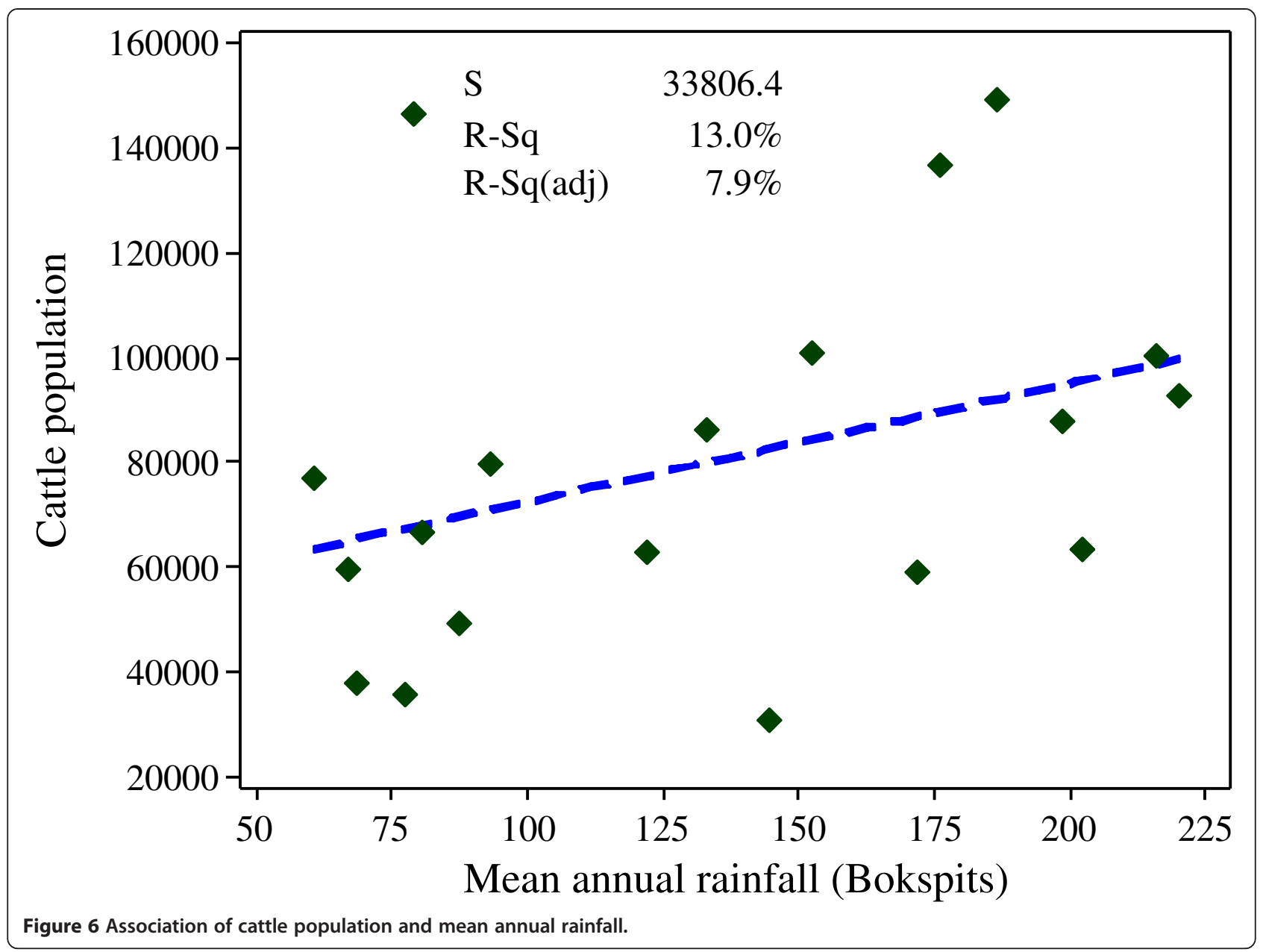

The cattle population also decreased with decreasing rainfall, but failed to show a significant relationship with mean annual rainfall. The results are consistent with another study that found that climate variability affects pasture productivity in Africa, but not cattle performance (Stige et al. 2006). The lack of a significant relationship between cattle populations and rainfall levels observed in our study could be due to management interventions by the pastoral communities to protect their investments (Stige et al. 2006).

On the contrary, Angassa and Oba (2007) observed that rainfall variability influenced cattle population dynamics

Table 3 Pastoral communities drought adaptation strategies

\begin{tabular}{llllll}
\hline $\begin{array}{l}\text { Adaptation } \\
\text { strategy }\end{array}$ & \multicolumn{3}{l}{ Pastoral community } & & \\
\cline { 2 - 4 } & $\begin{array}{l}\text { Bokspits } \\
(\boldsymbol{n}=\mathbf{4 0})\end{array}$ & $\begin{array}{l}\text { Vaalhoek } \\
(\boldsymbol{n}=\mathbf{3 1 )}\end{array}$ & $\boldsymbol{X}^{\mathbf{2}}$ & $\boldsymbol{P}$-value \\
\hline Destocking & 82.5 & 83.9 & 0.023 & $>0.05$ \\
Supplementary feeding & 80.0 & 100 & 6.99 & $<0.05$ \\
Mobility & 67.5 & 41.9 & 4.6 & $<0.05$ \\
\hline
\end{tabular}

under communal as well as ranching management systems in Ethiopia, and their finding was further confirmed by others (Alemayehu and Fantahun 2012). The observation on cattle responses to rainfall variability in eastern Africa differs from our results. The differences could be attributed to the fact that the cattle production system in Botswana is relatively less dependent on natural resources as compared to that in Ethiopia. Supplementation and new water sources alter the dynamics of non-equilibrium rangeland ecosystems (Wehrden et al. 2012), and this could have decoupled the cattle population and rainfall variability.

\section{Communities adaptation to rainfall variability}

The pastoral communities applied different adaptation strategies to reduce the impact of drought on their livestock productivity, but their over-reliance on livestock makes them more vulnerable to climate shocks (Sherwood 2013). In the Kgalagadi study area, pastoralists used feed supplementation to sustain their livestock, noted elsewhere in Botswana (Mogotsi et al. 2011). This strategy is partially facilitated by government through subsidization of animal feeds during drought at the Livestock Advisory 
Centre located at Bokspits. The pastoralists also used locally available feed resources like Acacia pods to supplement their animals. In addition, pastoralists tend to destock some of their cattle during drought as suggested in other studies (Mogotsi et al. 2011). This strategy works sufficiently for cattle because there is a well-organized market through the Botswana Meat Commission. However, there is no well-organized market for goats and sheep and pastoralists are therefore not able to sell these in time. This could also explain why the goat population tends to be more responsive to rainfall variability. Pastoral farmers in Botswana can also rely on drilled boreholes for water supplies in droughts.

Mobility was another strategy used to cope with drought, because Bokspits area exhibits spatial vegetation heterogeneity between sand dunes, which influences forage availability for grazing animals (Scoones 1995). Therefore, livestock mobility is necessary to effectively use the heterogeneous vegetation and widely practised in communal rangelands of Africa to cope with drought (Samuels et al. 2013). But pasture land reforms such as the Tribal Grazing Land Policy (TGLP) of Botswana, which promotes fencing and privatization of communal land, limit the ability of pastoralists and farmers to move their livestock between grazing areas. This could also explain why this strategy was least used by pastoralists at Bokspits as there are fenced ranches around their grazing lands. Though mobility is widely practised across Africa, it needs to be wellplanned; otherwise, animals could be crowded in one area especially during droughts, leading to overgrazing, range degradation and eventually increased livestock mortality (Nkedianye et al. 2011).

\section{Conclusion}

Kgalagadi South is characterized by frequent normal to mild droughts and infrequent moderate droughts as indicated by a high rainfall coefficient of variation and low SPI indexes. The impact of recurring droughts tends to lead to decline in livestock populations, particularly goats. The weak association between livestock populations, especially cattle and rainfall variability, suggests that management practices are buffering the impacts of climate shocks. Current pastoral farmers adaptation strategies include destocking, feed supplementation and mobility. The sustainability of mobility as an adaptation practice is questionable due to continued promotion of the Tribal Grazing Land Policy, which will result in most communal grazing land being managed as private ranches. Hence, there is a need for an improved drought management policy that would complement pastoral farmers adaptation practices and improve resilience to drought.

\section{Competing interests}

The authors declare that they have no competing interests.

\section{Authors contributions}

OK developed the concept, collected the data, carried out the data analysis and drafted the manuscript. NB provided the rainfall data and commented on the manuscript. Both authors approved the final manuscript.

\section{Authors information}

OK (Ph.D.) is an ecologist at the Department of Agricultural Research and carries out research on ecosystem management and climate change. NB is a Professor in Earth and Environmental Systems and Lead Researcher in Climate Change at Botswana Institute for Technology Research and Innovation.

\section{Acknowledgements}

Thanks to Indegeneous Vegetation Project (IVP) for funding and provision of Map. Professor Gufu Oba advice and guidance during the study is appreciated. Thanks to Kgalagadi community, A. Moroke, K. Dintwe, and enumerators for their support during fieldwork. Gratitute to Department of Meterological Services and Ministry of Agriculture for providing secoondary data.

\section{Author details}

${ }^{1}$ Department of Agricultural Research, Private Bag 033, Gaborone, Botswana. ${ }^{2}$ Botswana Institute for Technology Research and Innovation, Private Bag 0082, Gaborone, Botswana.

Received: 13 June 2014 Accepted: 21 October 2014

Published online: 24 December 2014

\section{References}

Alemayehu, K, and T Fantahun. 2012. The effect of climate change on ruminant livestock population dynamics in Ethiopia. Livestock Research for Rural Development 24(10):185.

Angassa, A, and G Oba. 2007. Relating long-term rainfall variability to cattle population dynamics in communal rangelands and a government ranch in southern Ethiopia. Agricultural Systems 94:715 725.

Batisane, N. 2011. The spatio-temporal-severity dynamics of drought in Botswana. Journal of Environmental Protection 2:803 816

Begzsuren, S, JE Ellis, DS Ojima, MB Coughenour, and T Chuluun. 2004. Livestock responses to droughts and severe winter weather in the Gobi Three Beauty National Park, Mongolia. Journal of Arid Environments 59: 785796

Best, AS, K Johst, T Munkemuller, and JMJ Travis. 2007. Which species will successfully track climate change? The influence of intraspecific competition and density dependent dispersal on range shifting dynamics. Oikos 116:1531 1539

Burgess, J. 2003. Country pasture/forage resource profile (Botswana). http://www. fao.org/ag/AGP/AGPC/doc/counprof/PDF\%20files/Botswana.pdf (accessed 24/11/2014)

CSO. 1996. Agricultural Census Report. Gaborone, Botswana: Central Statistics Office.

CSO. 2001. National Census Report. Gaborone. Botswana: Central Statistics Office Desta, S, and DL Coppock. 2002. Cattle population dynamics in the southern Ethiopian rangelands, 1980 97. Journal of Range Management 55:439 451.

Ellis, JE, and KA Galvin. 1994. Climate patterns and land-use practices in the dry zones of Africa. BioScience 44:340 349

Ellis, JE, and DM Swift. 1988. Stability of African pastoral ecosystem: alternate paradigms and implications for development. Journal of Range Management 41:450 459

Eriksen, S, and JA Silva. 2009. The vulnerability context of a savanna area in Mozambique: household drought coping strategies and responses to economic change. Environmental Science and Policy 12:33 52.

IPCC. 2013. Summary for policymakers. In Climate change 2013. The physical science basis. Contribution of Working Group 1 to the Fifth Assessment Report of the Intergovernmental Panel on Climate Change, ed. TE Stocker, D Qin, GK Plattner, M Tignor, SK Allen, J Boschung, A Nauels, Y Xia, V Bex, and PM Midgley. Cambridge and New York: Cambridge University Press. http://www.ipcc.ch/report/ar5/wg1/. Accessed 14 Oct 2014.

IVP BOT. 2004. Kgalagadi Situational Analysis. Gaborone, Botswana: Indigenous Vegetation Project.

Lioubimtseva, E, and GM Henebry. 2009. Climate and environmental change in arid Central Asia: impacts, vulnerability, and adaptations. Journal of Arid Environments 73:963 977 . 
Mapiye, C, M Chimonyo, and K Dzama. 2009. Seasonal dynamics, production potential and efficiency of cattle in the sweet and sour communal rangelands in South Africa. Journal of Arid Environments 73:529 536.

Masike, S, and P Urich. 2008. Vulnerability of traditional beef sector to drought and the challenges of climate change: The case of Kgatleng District, Botswana. Journal of Geography and Regional Planning 1:012 018 .

McCabe, JT. 1987. Drought and recovery: livestock dynamics among the Ngisonyoka Turkana of Kenya. Human Ecology 15:371 389.

Mogotsi, K, MM Nyangito, and DM Nyariki. 2011. Drought management strategies among agro-pastoral communities in non-equilibrium Kalahari ecosystems. Environmental Research Journal 5:156 162.

Mogotsi, K, MM Nyangito, and DM Nyariki. 2012. Vulnerability of rural agro-pastoral households to drought in semi-arid Botswana. Livestock Research for Rural Development 24(10):183.

Nkedianye, D, J de Leeuw, JO Ogutu, MY Said, TL Saidimu, SC Kifugo, DS Kaelo, and RS Reid. 2011. Mobility and livestock mortality in communally used pastoral areas: the impact of the 20052006 drought on livestock mortality in Maasailand. Pastoralism: Research, Policy and Practice 1:17.

Oba, G. 2001. The effect of multiple droughts on cattle in Obbu, Northern Kenya. Journal of Arid Environments 49:375 386

Oba, G, NC Stenseth, and WJ Lusigi. 2000. New perspectives on sustainable grazing management in arid zones of sub-Saharan Africa. Bioscience 51:35 51.

Ogutu, JO, HP Piepho, HT Dublin, N Bhola, and RS Reid. 2007. El Ni?o-Southern Oscillation, rainfall, temperature and Normalized Difference Vegetation Index fluctuations in the Mara-Serengeti ecosystem. African Journal of Ecology 46:132 143.

Perkins, JS. 1991. Drought, cattle-keeping, and range degradation in the Kalahari, Botswana. In Pastoral Economies in Africa and Long-Term Responses to Drought. Proceedings of a Colloquium at the University of Aberdeen, April 1990, ed. JC Stone, 287. Aberdeen: Aberdeen University African Studies Group.

Samuels, I, N Allsopp, and MT Hoffman. 2013. How could herd mobility be used to manage resources and livestock grazing in semi-arid rangeland commons? African Journal of Range \& Forage Science 30(1\&2):85 89.

Scoones, I. 1995. Exploiting heterogeneity: habitat use by cattle in dryland Zimbabwe. Journal of Arid Environments 29:221 232.

Sherwood, A. 2013. Community adaptation to climate change: exploring drought and poverty traps in Gituamba location, Kenya. Journal of Natural Resources Policy Research 5:147 161

Sithole, A, and CTF Murewi. 2009. Climate variability and change over Southern Africa: Impacts and Challenges. African Journal of Ecology 47: 1720.

Stige, LC, J Stave, K Chan, L Ciannelli, N Pettorelli, M Glantz, HR Herrem, and NC Stenseth. 2006. The effect of climate variation on agro-pastoral production in Africa. PNAS 103:3049 3053.

Stringer, LC, JC Dyer, MS Reed, AJ Dougill, C Twyman, and DD Mkwambisi. 2009. Adaptations to climate change, drought and desertification: local insights to enhance policy in southern Africa. Environmental Science and Policy 12:748 765.

Sulieman, HM, and NA Elagib. 2012. Implications of climate, land-use and land-cover changes for pastoralism in eastern Sudan. Journal of Arid Environments 85:132 141 .

Thomas, DSG, D Sporton, and J Perkins. 2000. The environmental impact of livestock ranches in the Kalahari, Botswana: natural resource use, ecological change and human response in a dynamic dryland system. Land Degradation and Development 11:327 341

Thornton, PK, J van de Steeg, A Notenbaert, and M Herrero. 2009. The impacts of climate change on livestock and livestock systems in developing countries: a review of what we know and what we need to know. Agricultural Systems 101:113 127

Toulmin, C. 1996. Tracking through drought: options for destocking and restocking. In Living with Uncertainty: New Directions in Pastoral Development in Africa, ed. I Scoones. London: International Institute for Environment and Development. Intermediate Technology Publication.

Vetter, S. 2005. Rangelands at equilibrium and non-equilibrium: recent developments in the debate. Journal of Arid Environments 62:321 341.
Ward, D, D Saltz, and BT Ngairorue. 2004. Spatio-temporal rainfall variation and stock management in arid Namibia. Journal of Range Management 57:130 140.

Wehrden, HV, J Hanspach, P Kaczenky, J Fischer, and K Wesche. 2012. Global assessment of the non-equilibrium concept in rangelands. Ecological Applications 22:393 399.

Westoby, M, BH Walker, and I Nor-Meir. 1989. Opportunistic management for rangelands not at equilibrium. Journal of Range Management 42:266 274

doi:10.1186/s13570-014-0019-0

Cite this article as: Kgosikoma and Batisani: Livestock population dynamics and pastoral communities adaptation to rainfall variability in communal lands of Kgalagadi South, Botswana. Pastoralism: Research, Policy and Practice 2014 4:19.

\section{Submit your manuscript to a SpringerOpen ${ }^{\odot}$ journal and bene冈t from:}

- Convenient online submission

- Rigorous peer review

- Immediate publication on acceptance

- Open access: articles freely available online

- High visibility within the 囚eld

- Retaining the copyright to your article

Submit your next manuscript at $>$ springeropen.com 